\title{
Overview of clay as supplementary cementitious material
}

\author{
Matea Flegar ${ }^{1}$, doc.dr.sc. Marijana Serdar², dr.sc. Diana Londono-Zuluaga ${ }^{3}$, \\ prof.dr.sc. Karen Scrivener ${ }^{4}$ \\ ${ }^{1}$ University of Zagreb, Faculty of Civil Engineering, Department of Materials, mflegar@grad.hr \\ ${ }^{2}$ University of Zagreb, Faculty of Civil Engineering, Department of Materials, mserdar@grad.hr \\ ${ }^{3}$ Laboratory of Construction Materials, École Polytechnique Fédérale de Lausanne, Switzerland, \\ diana.Iondonozuluaga@epfl.ch \\ ${ }^{4}$ Laboratory of Construction Materials, École Polytechnique Fédérale de Lausanne, Switzerland, \\ karen.scrivener@epfl.ch
}

\begin{abstract}
Locally available materials, like clays, present a potential to meet the growing concrete demand and to produce more sustainable material. This paper reviews the behaviour of common clay minerals (kaolinite, illite and montmorillonite) giving an insight into the complexity of clay soils that usually appear as mixtures of minerals and impurities. It is therefore crucial to perform reactivity study when considering clay as supplementary cementitious material (SCM). The paper also shows major clay excavation sites in Croatia highlighting those which will be a part of the Swiss-Croatian research project ACT.
\end{abstract}

Key words: SCM, clay minerals, clay activation, calcination, reactivity

\section{Upotreba glina kao mineralnih dodataka cementu}

\section{Sažetak}

Lokalno dostupni materijali, poput gline, predstavljaju potencijal koji može zadovoljiti rastuću potrošnju betona, ujedno i potrebu za održivom izgradnjom. Ovaj rad prikazuje ponašanja uobičajenih minerala gline (kaolinit, ilit i montmorilonit) objašnjavajući složenu strukturu gline koja se obično javlja kao mješavina minerala i nečistoća. Iz tog je razloga važno odrediti reaktivnost gline prilikom razmatranja njene primjene kao dodatka cementnu. Ovaj rad također predstavlja pregled značajnijih nalazišta gline u Hrvatskoj, ističući ona koja će biti dio švicarsko-hrvatskog istraživačkog projekta ACT.

Ključne riječi: mineralni dodaci cementu, minerali glina, aktivacija gline, kalcinacija, reaktivnost 


\section{Introduction}

Current production of Portland cement clinker accounts for 5 to $8 \%$ of the global $\mathrm{CO}_{2}$ emissions [1]. Considering the constant growth of the building industry, if there are no actions taken, according to the worst case scenario, until 2050 the cement production could count for more than $25 \%$ of the overall emissions [2]. For the production of 1 ton of cement clinker an average of 0.67 to 0.8 tonnes of $\mathrm{CO}_{2}$ is produced (depending on the fuel type and blends) [3]. There are two ways in which the $\mathrm{CO}_{2}$ emits while producing Portland cement. About $40-50 \%$ is released while heating the cement kiln on the temperature of $1450^{\circ} \mathrm{C}$, and the rest (50-60 \%) comes from decarbonation of calcium carbonate $\left(\mathrm{CaCO}_{3}\right)$. The $\mathrm{CaCO}_{3}$ content in raw materials used for Ordinary Portland cement production is about 75 to $79 \%$ [4], making partial replacement of clinker with supplementary cementitious materials (SCMs) a promising option for a more ecological production of concrete.

Certain industrial by-products show encouraging results in the clinker substitution [5-7]. Fly ash from coal power plants and steel furnace slags have been broadly used as SCMs, but the reserves of these materials are not sufficient to satisfy the cement production demand. The amount of industrial by-products available depends on the production of this industry, which means it is relying on the local economic development and not controlled by the cement industry [8]. Therefore, there is a need to focus on accessible materials that can supply the growing demand of cement usage. With its abundance all over the world and its low cost, clay and its alternations (obtained with calcination) could be a part of the solution that is needed. Currently, researchers are exploring the possibilities of different clay types that could be efficiently used as a SCM. The Swiss-Croatian collaborative project $A C T$ is a part of this research, investigating the potential of locally available clay as partial replacement in standard and high-performance concrete.

\section{Types and mineralogical composition of clay materials}

According to the Association Internationale pour l'Etude des Argiles (AIPEA) and the Clay Minerals Society (CMS), clay is defined as: ", naturally occurring material composed primarily of fine-grained minerals, which is generally plastic at appropriate water content and will harden with (sic) dried or fired" [9]. "Clay minerals" are phyllosilicate minerals that contribute to the plasticity of clay and which harden while drying or firing [9]. Although particle size is often mentioned as the key parameter for defining clay, there is no generally accepted granulometry. In geoengineering the maximum size of the clay grain is $2 \mu \mathrm{m}$ [10], other sciences set the limit lower. Parameters like plasticity are also mentioned, in terms of "plasticity index" 
(PI) which shows the difference in water content between the liquid and the plastic limit of soil [11]. In practice clays can be divided into four main types:

- bentonites predominantly composed of montmorillonite (smectite)

- kaolins consisting of kaolinite

- palygorskite and sepiolite which are a group of minerals mostly made of hydrated magnesium silicates

- "common clays" most often consisting of diverse variations of clay minerals, but often containing illite or smectite [11].

Clay minerals in general are generated by weathering of silicates in rocks such as feldspar, micas, etc. Their structure is formed from tens or hundreds of layers with a combination of aluminium and silicon sheets. Each sheet is constructed out of tetrahedral or octahedral connections shown in the Figure 1. In the silica layer silicon is surrounded by bonds to four oxygen atoms so that they form a tetrahedral arrangement. The formation of a layer is derived by connecting tetrahedral that share one oxygen ion. The octahedral group forms around one aluminium that is connected to six oxygen ions, which then form the alumina sheets.

a)

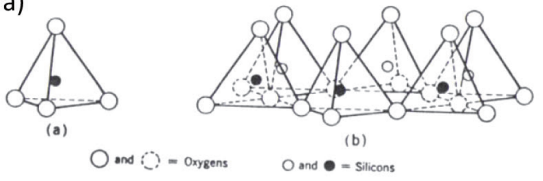

b)

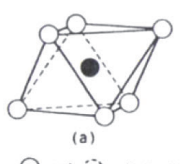

$O$ and - Hydroxyls
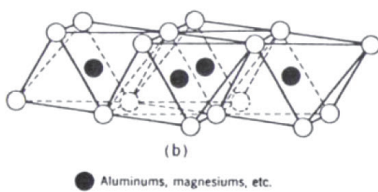

Figure 1. a) Silicon tetrahedron and silica tetrahedra arranged in a hexagonal network. b) Octahedral unit and alumina octahedral sheet structure [12]

Most commonly found clay minerals that contribute to clay formation are kaolinite, illite and montmorillonite. The representation of their structure given by Fernandez et al. [13] that was adapted from Grim [14], shows the difference in layer composition and the chemical formulation of the 3 minerals (Figure 2). Kaolinite is formed by repeating layers in combination of one silica sheet and one alumina sheet (1:1 mineral). The sheets are linked by hydrogen bonding which forms a strong bond leading to its non-swelling property [11]. The other two clays structures have the unit layer composed of two tetrahedrons silicon sheets wedged around an alumina octahedral sheet (2:1 layer group). 
c)

b)

a)
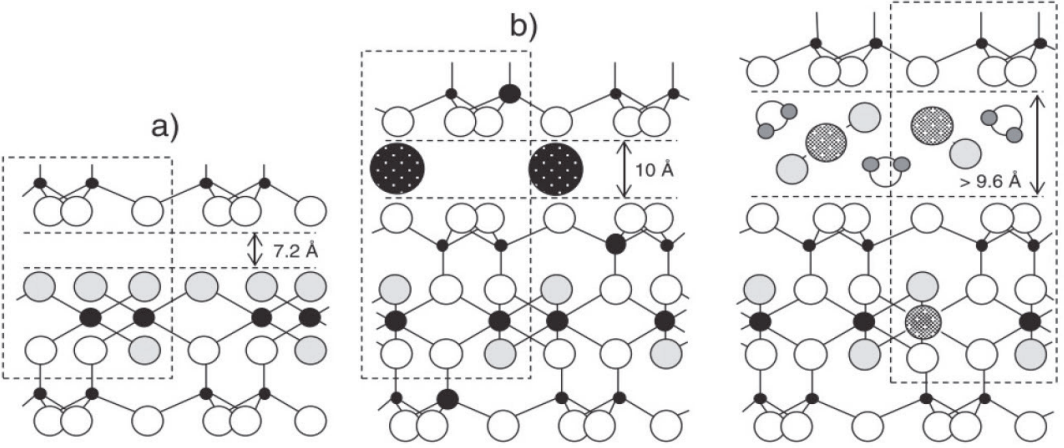

$\mathrm{Al}_{2} \mathrm{Si}_{2} \mathrm{O}_{5}(\mathrm{OH})_{4}$

$\left(\mathrm{Si}_{4}\right)(\mathrm{Al}, \mathrm{Mg}, \mathrm{Fe})_{2.3} \mathrm{O}_{10}(\mathrm{OH})_{2} \cdot\left(\mathrm{K}, \mathrm{H}_{2} \mathrm{O}\right) \quad \mathrm{Na}_{0.33}\left(\mathrm{Al}_{1.67} \mathrm{Mg}_{0.33}\right) \mathrm{Si}_{2} \mathrm{O}_{10}(\mathrm{OH})_{2} \cdot\left(\mathrm{H}_{2} \mathrm{O}\right)$

\begin{tabular}{|llll}
\hline$: \mathrm{Si}$ & & $\because \mathrm{O}$ & \\
$\mathrm{O}$ & $\mathrm{Al}$ & $\mathrm{O}$ & $\mathrm{K}$ \\
$\mathrm{O}: \mathrm{H}$ & $\mathrm{OH}$ & $\mathrm{Ca}, \mathrm{Mg}, \mathrm{Na} \ldots$ \\
\end{tabular}

Figure 2. Structure and ideal formulas of clay minerals a) kaolinite, b) illite and c) montmorillonite [13]

Naturally, more than only these three minerals can be found in the soil. It is often that interstratifications of two or more layers can occur in nature [11]. Also, isomorphous substitution of cations in these type of sheets is frequent. In tetrahedral sites $\mathrm{Si}^{4+}$ can be substituted by $\mathrm{Al}^{3+}$, octahedral sites are generally occupied by $\mathrm{Mg}^{2+}$ and other cations like $\mathrm{Fe}^{3+}, \mathrm{Cr}^{3+}$, etc $[15,16]$.

\section{Reactivity of clay materials}

According the ASTM C125 [17] terminology pozzolan is a siliceous and aluminous material which, in itself, possesses little or no cementitious value but which will, in finely divided form in the presence of moisture, react chemically with calcium hydroxide at ordinary temperature to form compounds. Clays, in its natural forms, do not possess pozzolanic properties. The activation of clay material happens when their crystalline structure is converted into an amorphous or disordered state. This can be accomplished by mechanical, chemical or thermal treatments of the raw material. Mechanical methods include treatments based on prolonged grinding. Numerous studies show satisfactory results in terms of amorphization and dehydroxylation of kaolinite phases and an increase in specific surface area [18-20]. Chemically clay can be activated using acid or alkaline activators which promotes solubility of silica and alumina depending on the method and clay minerals in the sample $[21,22]$. Thermal methods imply heating of samples to remove structural water which is a process called calcination [20] and which will be explained below. 


\subsection{Calcination}

Thermally activating clay minerals by calcination changes their crystalline structure. By transforming into amorphous phases, the pozzolanic reactivity of clay increases. With the variety of clay materials, the pozzolanic activation is depended on their mineralogy, strain in the bonds, the heating rate, and the impurities present in the material [23]. There are four main reactions that take place in clays when thermally treated at different temperatures:

- dehydration - loss of structure and absorbed water $<180^{\circ} \mathrm{C}$

- dehydroxylation between $180-500^{\circ} \mathrm{C}$

- structure breakdown - rupture of bonds and collapse of clay structure 600 $800^{\circ} \mathrm{C}$

- recrystallization - formation of new high temperature phases between 900 $1000^{\circ} \mathrm{C}[24]$.

Pozzolanic reactivity of clay is depended on the completion of the dehydroxylation process, the obtained specific surface area, avoiding recrystallisation and the amount of incorporated clay and non-clay material [25].

The derivative thermo-gravimetric (DTG) curves in the Figure $3 \mathrm{a}$ ), b) and c) show the loss of mass during heating for the three main minerals: kaolinit, illite and montmorillonite, respectively.

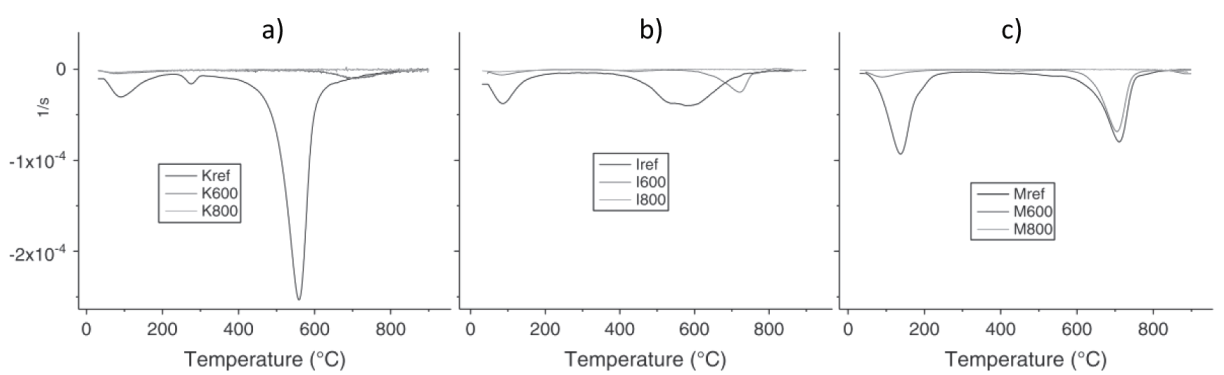

Figure 3. DTG curves of tree clay minerals and their calcined products: a) kaolinite, b) illite, c) montmorillonite [13]

The presented curves show the difference between the raw material (reference) and their calcined product (heated on 600 and $800^{\circ} \mathrm{C}$ ). The first slight loss is observed between $30-200^{\circ} \mathrm{C}$, the loss of absorbed water. Montmorillonite shows more significant release of water. The dehydroxylation process is observed in the range of $400-800^{\circ} \mathrm{C}$, where kaolinite shows the most weight loss and therefore produces more anhydrous phases. The position of the peak in this range is depended on the structure and the binding of hydroxyls, whereas the shape of the curve and the range vary on the crystallinity or the particle size distribution [13]. 


\subsection{Assessing reactivity of clay in cement pastes}

There are a few techniques that can be used for the identification and quantification of the hydration products in a blended cement paste. X-Ray diffraction together with Rietveld analysis is one of them, and has been used in numerous studies [20], [26]. In the study done by Fernandez and Scrivener [27] the reduction of $\mathrm{CH}$ peaks in different calcined clay blended systems was used as an indication of their reactivity (Figure 4).

From the figure, it can be noted that calcined kaolin mixtures (K600, K800) show a significant reduction of the $\mathrm{CH}$ component. The same cannot be concluded for the illite $(1600,1800)$ and montmorillonite (M600, M800) mixtures, even though there is a small reduction of the peaks in the montmorillonite blends.

XRD results combined with thermogravimetric analysis allow quantification of the $\mathrm{CH}$ consumption in the hydration process. It is observed in Figure $4 \mathrm{~b}$ ) that only calcined kaolinite effectively consumes portlandite, followed by montmorillonite calcined at $600^{\circ} \mathrm{C}$.

a)

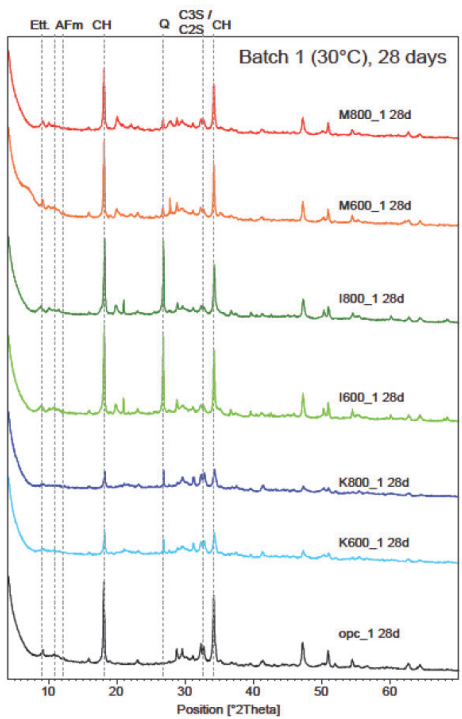

b)

\begin{tabular}{|c|c|c|c|}
\hline - k600_ & - i600_1 & $\cdots-m 600 \_1$ & --n- filler_ \\
\hline$\cdots-k 8$ & $-\cdots-\cdot i 800_{-}^{-} 1$ & $\cdots$ m800_1 & $-\cdots o p c$ \\
\hline
\end{tabular}

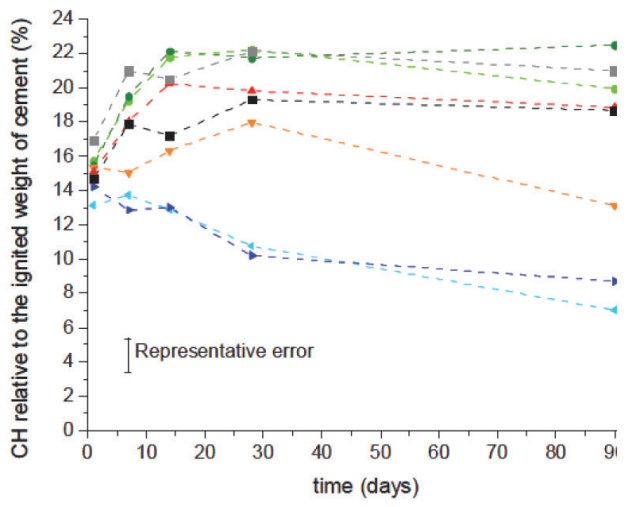

Figure 4. a) 28 days XRD patterns of blended clay cement pastes, b) Calcium hydroxide (CH) content at different ages of clay cement pastes [27] 


\section{Availability of clay in Croatia}

Croatia is located at the intersection of Central Europe, the Balkans Peninsula and the Mediterranean. Geologically, the land is divided into two main provinces, the Pannonian basin and the Dinarides which differ in geographic and geological aspects. Most of the clays settlements can be found in the northern parts of the region, associated with the Pannonian basin [28].

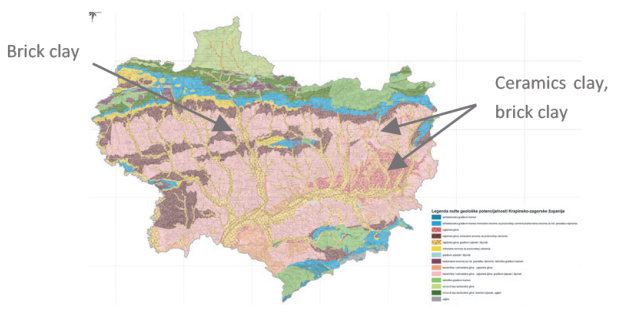

a) Krapina-Zagorje County

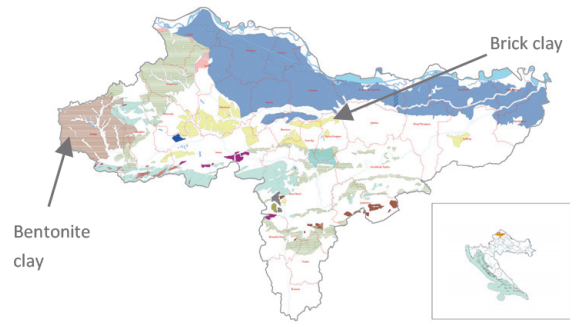

c) Varaždin County

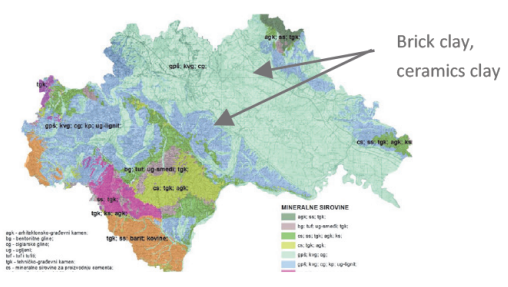

b) Sisak-Moslavina County

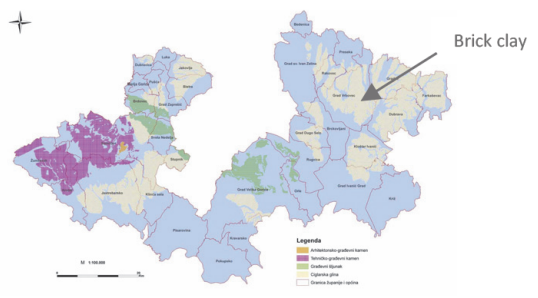

d) Zagreb County

Figure 5. Clay deposits in four northern regions in Croatia [29-32]

Grizelj et. al. [33] have performed mineralogical and geochemical characterization of sedimentary rocks in the Croatian part of Pannonian Basin. The most common minerals they found in the fifty-two samples are smectite or illite smectite, even though there are some minor portions of kaolinite and illite in all samples. Crnički, J. and Šinkovec, B. [28] state the raw materials used for the brick industry in the region are composed of montmorillonite-kaolinite-illite type of clays.

Table 1 presents the collected data on current state of clay excavation sites in Croatia. From the list of 32 excavation sites [34] dating from 2015, only eleven sites and factories are currently in function. The rest of the mentioned concessioners have closed the excavation sites due to economic reasons, either the high cost of up keeping the sites or the low production value. Although the number of active clay excavation sites is reasonably low, the number of previously existing ones points out the broadness of clay deposit the region. 
Table 1. Excavation sites of clay in the Republic of Croatia with indicated sites from which samples are collected for ACT project

\begin{tabular}{|c|c|c|c|c|c|}
\hline \multicolumn{6}{|c|}{ Excavation sites in Republic of Croatia } \\
\hline Nb. & $\begin{array}{c}\text { Excavation } \\
\text { site }\end{array}$ & Concession & $\begin{array}{l}\text { Type of } \\
\text { Clay }\end{array}$ & $\begin{array}{c}\text { Total } \\
\text { recourses } \\
\text { [ha] }\end{array}$ & Notes \\
\hline \multicolumn{6}{|c|}{ Zagreb County } \\
\hline 1 & $\begin{array}{l}\text { Zapadno } \\
\text { glinište }\end{array}$ & Tempo d.d. & Brick clay & 10,35 & $\begin{array}{l}\text { Brick } \\
\text { factory } \\
\text { closed }\end{array}$ \\
\hline 2 & Vrbovec & Gradip d.d. & Brick clay & 31,46 & $\begin{array}{l}\text { Brick } \\
\text { factory } \\
\text { closed }\end{array}$ \\
\hline 3 & Mraclin & $\begin{array}{l}\text { Ciglana } \\
\text { Mraclin } \\
\text { d.o.o. }\end{array}$ & Brick clay & 48,55 & $\begin{array}{c}\text { Excavation } \\
\text { site } \\
\text { closed }\end{array}$ \\
\hline 4 & Pedalj & Inker d.d & $\begin{array}{c}\text { Ceramics } \\
\text { clay }\end{array}$ & no record & $\begin{array}{c}\text { Excavation } \\
\text { site } \\
\text { closed }\end{array}$ \\
\hline \multicolumn{6}{|c|}{ Zagreb City } \\
\hline 5 & Novaĉica & $\begin{array}{c}\text { Termoblok } \\
\text { d.o.o., }\end{array}$ & Brick clay & 88,06 & $\begin{array}{l}\text { Brick } \\
\text { factory } \\
\text { closed }\end{array}$ \\
\hline 6 & Soblinec & $\begin{array}{l}\text { Vodoprivreda } \\
\text { zagreb d.d. }\end{array}$ & Brick clay & 8,1 & $\begin{array}{c}\text { Excavation } \\
\text { site } \\
\text { closed }\end{array}$ \\
\hline \multicolumn{6}{|c|}{ Varaždin County } \\
\hline 7 & $\begin{array}{l}\text { Cerje } \\
\text { Tužno }\end{array}$ & $\begin{array}{l}\text { Ciglana Cerje } \\
\text { Tužno d.o.o. }\end{array}$ & Brick clay & 54,47 & $\begin{array}{l}\text { Samples } \\
\text { collected }\end{array}$ \\
\hline 8 & Čret & $\begin{array}{l}\text { Ciglana Cerje } \\
\text { Tužno d.o.o. }\end{array}$ & Brick clay & 27,14 & $\begin{array}{l}\text { Excavation } \\
\text { site } \\
\text { closed }\end{array}$ \\
\hline 9 & Cukavec I & \multirow{2}{*}{$\begin{array}{l}\text { Leier -Leitl } \\
\text { d.o.o. }\end{array}$} & Brick clay & 17,04 & $\begin{array}{l}\text { Samples } \\
\text { collected }\end{array}$ \\
\hline 10 & Cukavec II & & Brick clay & 7,4 & $\begin{array}{l}\text { Samples } \\
\text { collected }\end{array}$ \\
\hline 11 & $\begin{array}{l}\text { Ludbreški } \\
\text { vinogradi }\end{array}$ & $\begin{array}{c}\text { Ciglana } \\
\text { Kovačić d.o.o. }\end{array}$ & Brick clay & 8,84 & $\begin{array}{c}\text { Brick } \\
\text { factory } \\
\text { closed }\end{array}$ \\
\hline 12 & Lukavec & $\begin{array}{l}\text { Ciglana Cerje } \\
\text { Tužno d.o.o. }\end{array}$ & Brick clay & 32,86 & $\begin{array}{c}\text { Excavation } \\
\text { site } \\
\text { closed }\end{array}$ \\
\hline \multicolumn{6}{|c|}{ Međimurje County } \\
\hline 13 & Šenkovec & $\begin{array}{c}\text { Eko } \\
\text { Međimurje } \\
\text { d.d }\end{array}$ & Brick clay & 59,4 & $\begin{array}{l}\text { Brick } \\
\text { factory } \\
\text { closed }\end{array}$ \\
\hline \multicolumn{6}{|c|}{ Koprivnica-Križevci County } \\
\hline 14 & Gušćerovac & Radnik d.d. & Brick clay & 12 & $\begin{array}{l}\text { Brick } \\
\text { factory } \\
\text { closed }\end{array}$ \\
\hline 15 & Ribnjak & IGMA d.o.o. & Brick clay & 3 & $\begin{array}{l}\text { Brick } \\
\text { factory } \\
\text { closed }\end{array}$ \\
\hline \multicolumn{6}{|c|}{ Bjelovar-Bilogora County } \\
\hline 16 & Garešnica & Finang d.d. & Brick clay & 22,55 & $\begin{array}{l}\text { Brick } \\
\text { factory } \\
\text { closed }\end{array}$ \\
\hline
\end{tabular}

\begin{tabular}{|c|c|c|c|c|c|}
\hline \multicolumn{6}{|c|}{ Excavation sites in Republic of Croatia } \\
\hline Nb. & $\begin{array}{c}\text { Excavation } \\
\text { site }\end{array}$ & Concession & $\begin{array}{l}\text { Type of } \\
\text { Clay }\end{array}$ & $\begin{array}{c}\text { Total } \\
\text { recourses } \\
\text { [ha] }\end{array}$ & Notes \\
\hline 17 & Dominikovica & Bilodom d.o.o. & Brick clay & 3,35 & $\begin{array}{l}\text { Brick } \\
\text { factory } \\
\text { closed }\end{array}$ \\
\hline 18 & Paulovac & Pavliš d.o.o. & Brick clay & 19,88 & $\begin{array}{l}\text { Brick } \\
\text { factory } \\
\text { closed }\end{array}$ \\
\hline \multicolumn{6}{|c|}{ Virovitica-Podravina County } \\
\hline 19 & Sladojevci & $\begin{array}{c}\text { Cliglana IGM } \\
\text { d.o.o. }\end{array}$ & Brick clay & 12,52 & $\begin{array}{l}\text { Brick } \\
\text { factory } \\
\text { closed }\end{array}$ \\
\hline 20 & Bilo & Opeco d.o.o & Brick clay & 6,6 & $\begin{array}{c}\text { Brick } \\
\text { factory } \\
\text { closed }\end{array}$ \\
\hline 21 & Orahovica I & $\begin{array}{c}\text { Keramika } \\
\text { Modus d.o.o. }\end{array}$ & $\begin{array}{c}\text { Ceramics } \\
\text { clay }\end{array}$ & no record & $\begin{array}{l}\text { Samples } \\
\text { collected }\end{array}$ \\
\hline \multicolumn{6}{|c|}{ Vukovar-Srijem County } \\
\hline 22 & Dren & \multirow{2}{*}{$\begin{array}{l}\text { Dilj d.o.o. } \\
\text { Vinkovci }\end{array}$} & Brick clay & 30,88 & $\begin{array}{l}\text { Working } \\
\text { brick } \\
\text { production }\end{array}$ \\
\hline 23 & Slavonka & & Brick clay & 26,37 & $\begin{array}{l}\text { Working } \\
\text { brick } \\
\text { production }\end{array}$ \\
\hline 24 & Alvaluci & Razvitak d.d. & Brick clay & 15,98 & $\begin{array}{l}\text { Brick } \\
\text { factory } \\
\text { closed }\end{array}$ \\
\hline 25 & Cerna & $\begin{array}{c}\text { Kvalitet Cerna } \\
\text { d.d }\end{array}$ & Brick clay & 19,16 & $\begin{array}{l}\text { Brick } \\
\text { factory } \\
\text { closed }\end{array}$ \\
\hline \multicolumn{6}{|c|}{ Osijek-Baranja County } \\
\hline 26 & Kukljaš & Dilj d.o.o. & Brick clay & 32,5 & $\begin{array}{c}\text { Working } \\
\text { brick } \\
\text { production }\end{array}$ \\
\hline 27 & Sarvaš & Opeka d.d & Brick clay & 44,73 & $\begin{array}{l}\text { Brick } \\
\text { factory } \\
\text { closed }\end{array}$ \\
\hline 28 & Tomašanci & Opeka d.d & Brick clay & 36,83 & $\begin{array}{l}\text { Brick } \\
\text { factory } \\
\text { closed }\end{array}$ \\
\hline \multicolumn{6}{|c|}{ Karlovac County } \\
\hline 29 & Rečica & $\begin{array}{c}\text { Wienerberger } \\
\text { d.d. }\end{array}$ & Brick clay & 71,66 & $\begin{array}{l}\text { Samples } \\
\text { collected }\end{array}$ \\
\hline \multicolumn{6}{|c|}{ Krapina-Zagorje County } \\
\hline 30 & $\begin{array}{c}\text { Đurđevićev } \\
\text { Brijeg }\end{array}$ & $\begin{array}{l}\text { Wienerberger } \\
\text { d.d. }\end{array}$ & Brick clay & 56,62 & $\begin{array}{l}\text { Working } \\
\text { brick } \\
\text { production }\end{array}$ \\
\hline \multicolumn{6}{|c|}{ Sisak-Moslavina County } \\
\hline 31 & $\begin{array}{c}\text { Donja } \\
\text { Čemernica }\end{array}$ & \multirow{2}{*}{$\begin{array}{l}\text { Termoterra } \\
\text { d.o.o. }\end{array}$} & Brick clay & 55,76 & $\begin{array}{l}\text { Samples } \\
\text { collected }\end{array}$ \\
\hline 32 & Brkovec & & $\begin{array}{l}\text { Brick } \\
\text { clay }\end{array}$ & 22,32 & $\begin{array}{l}\text { Samples } \\
\text { collected }\end{array}$ \\
\hline
\end{tabular}


Most of the clay samples collected in Croatia so far consist only small portion of kaolinite. As discussed previously, kaolinite shows the highest potential for activation in cementitious materials, compared to illite and montmorillonite [13], which is the result of the difference in the order of its crystalline structure. Some studies [35] suggest even though cements containing other types of activated clays do not show as good results as the ones containing kaolinite, they show a possibility in the usage for lower strength concretes.

Nevertheless, a certain amount of kaolinite should be present in the clay that is used as a SCM to obtain an optimal reasoning for the substitution of cement. If the calcination temperature of clay reaches a value close to the current cement production $\left(1450^{\circ} \mathrm{C}\right)$ and has lower reactivity, the production of such blended cement could be considered economically unjustified. For that reason, it is important to establish the reactivity of the blended cement as well as the calcination temperature, which will be the next step in ACT project.

\section{Concluding remarks and outlook}

Usage of clay presents an important part in the development of low $\mathrm{CO}_{2}$ cementitious materials. Research has shown calcined clays can possess pozzolanic properties, depending of their mineralogical composition. Kaolinite has proven to have the highest pozzolanic activity, compared to illite and montmorillonite, independent on the calcination temperature. The low reactive clays have shown good results in the degree of hydration, which could potentially be enough for low strength concrete. Croatia and South-Eastern European region are considered to be rich in clay materials. Even though certain samples of clay from Croatia were already collected within Swiss-Croatian collaborative project ACT, up to now performed characterisation indicates that they contain only small amount of kaolinite. The aim in the forthcoming period of project ACT will be to locate other sources of clays in Croatia and the region, as well as to optimise the calcination temperature which yields maximum reactivity of chosen clays. Additionally, more research should be dedicated to the life cycle analysis of the production of calcined clay concrete, to validate suitability of locally available calcined clay for production of low $\mathrm{CO}_{2}$ cementitious materials.

\section{Acknowledgement}

The presented research is a part of a scientific project "Advanced low $\mathrm{CO}_{2}$ cementitious materials" - ACT, that is financed within the Croatian-Swiss Research Program of the Croatian Science Foundation and the Swiss National Science Foundation with funds obtained from the Swiss-Croatian Cooperation Programme. 


\section{Literature}

[1] E. M. Gartner and D. E. MacPhee, "A physico-chemical basis for novel cementitious binders," Cem. Concr. Res., vol. 41, no. 7, pp. 736-749, 2011.

[2] R. Snellings, "Assessing, Understanding and Unlocking Supplementary Cementitious Materials," RILEM Tech. Lett., vol. 1, pp. 50-55, 2016.

[3] F. Schorcht, I. Kourti, B. M. Scalet, S. Roudier, and L. Delgado Sancho, "Best Available Techniques (BAT) Reference Document for the Production of Cement, Lime and Magnesium Oxide," Luxembourg, 2013.

[4] K. L. Scrivener and A. Nonat, "Hydration of cementitious materials, present and future," Cem. Concr. Res., vol. 41, no. 7, pp. 651-665, 2011.

[5] K. Celik, C. Meral, M. Mancio, P. K. Mehta, and P. J. M. Monteiro, "A comparative study of self-consolidating concretes incorporating high-volume natural pozzolan or highvolume fly ash," Constr. Build. Mater., vol. 67, pp. 14-19, 2014.

[6] J. M. Manso, M. Losañez, J. A. Polanco, and J. J. Gonzalez, "Ladle Furnace Slag in Construction," J. Mater. Civ. Eng., vol. 17, no. 5, pp. 513-518, 2005.

[7] R. T. Thorstensen and P. Fidjestol, "Inconsistencies in the pozzolanic strength activity index (SAI) for silica fume according to EN and ASTM," Mater. Struct. Constr., vol. 48, no. 12, pp. 3979-3990, 2015.

[8] M. Schneider, M. Romer, M. Tschudin, and H. Bolio, "Sustainable cement productionpresent and future," Cem. Concr. Res., vol. 41, no. 7, pp. 642-650, 2011.

[9] S. Guggenheim et al., "Definition of clay and clay mineral: Joint report of the AIPEA nomenclature and CMS nomenclature committees," Clays Clay Miner., vol. 43, no. 2, pp. 255-256, 1995.

[10] A. Ito and R. Wagai, "Data Descriptor : Global distribution of clay-size minerals on land surface for biogeochemical and climatological studies," pp. 1-11, 2017.

[11] F. Bergaya, B. K. G. Theng, and G. Lagaly, Handbook of clay science. Elsevier, 2006.

[12] K. Mitchell, J. K, Soga, "Chapter 3 Soil Mineralogy," in Fundamentals of Soil Behhavior, 3rd ed., Hoboken: John Wiley \& Sons, 2005, pp. 35-82.

[13] R. Fernandez, F. Martirena, and K. L. Scrivener, "The origin of the pozzolanic activity of calcined clay minerals: A comparison between kaolinite, illite and montmorillonite," Cem. Concr. Res., vol. 41, no. 1, pp. 113-122, Jan. 2011.

[14] R. E. Grim, Applied Clay Mineralogy, Fifth. New York: McGraw Hill Text, 1962.

[15] R. S. Varma, "Clay and clay-supported reagents in organic synthesis," Tetrahedron, vol. 58, no. 7, pp. 1235-1255, 2002. 
[16] J. K. Mitchell and K. Soga, Fundamentals of soil behavior. Hoboken: John Wiley \& Sons, 2005.

[17] American Society for Testing and Materials ASTM Standard C125, "Standard Terminology Relating to Concrete and Concrete Aggregate," ASTM International. pp. 1-6, 2010.

[18] M. Fitos, E. G. Badogiannis, S. G. Tsivilis, and M. Perraki, "Pozzolanic activity of thermally and mechanically treated kaolins of hydrothermal origin," Appl. Clay Sci., vol. 116-117, pp. 182-192, 2015.

[19] B. Ilić, V. Radonjanin, M. Malešev, M. Zdujić, and A. Mitrović, "Effects of mechanical and thermal activation on pozzolanic activity of kaolin containing mica," Appl. Clay Sci., vol. 123, pp. 173-181, 2016.

[20] C. Vizcayno, R. M. de Gutiérrez, R. Castello, E. Rodriguez, and C. E. Guerrero, "Pozzolan obtained by mechanochemical and thermal treatments of kaolin," Appl. Clay Sci., vol. 49, no. 4, pp. 405-413, 2010.

[21] T. Jiang, G. Li, G. Qiu, X. Fan, and Z. Huang, "Thermal activation and alkali dissolution of silicon from illite," Appl. Clay Sci., vol. 40, no. 1-4, pp. 81-89, 2008.

[22] C. Belver, M. A. Bañares Muñoz, and M. A. Vicente, "Chemical activation of a kaolinite under acid and alkaline conditions," Chem. Mater., vol. 14, no. 5, pp. 2033-2043, 2002.

[23] C. Shi, "An overview on the activation of reactivity of natural pozzolans," Can. J. Civ. Eng., vol. 28, no. 5, pp. 778-786, 2011.

[24] R. L. Day, “Pozzolans for use in low-cost housing. A state of the art report," p. 164, 1990.

[25] A. K. Chatterjee, "Pozzolanicity of Calcined Clay," Springer, Dordrecht, 2015, pp. 83-89.

[26] K. L. Scrivener, T. Füllmann, E. Gallucci, G. Walenta, and E. Bermejo, "Quantitative study of Portland cement hydration by X-ray diffraction/Rietveld analysis and independent methods," Cem. Concr. Res., vol. 34, no. 9, pp. 1541-1547, 2004.

[27] R. Fernandez and K. Scrivener, "Calcined clayey soils as a potential replacement for cement in developing countries. Ph.D Thesis, Ecole Polytechnique Fédérale de Lausanne," 2009.

[28] J. Crnički and B. Šinkovec, "Nemetalne Mineralne Sirovine Hrvatske," Rud. Zb., vol. 5, no. 1, pp. 21-37, 1993.

[29] Ž. Dedić et al., “Rudarsko-geološka studija Krapinsko-zagorske županije," Zagreb, 2014.

[30] B. Kruk et al., "Rudarsko-geološka studija sisačko-moslavačke županije," Zagreb, 2016.

[31] Ž. Dedić, B. Kruk, L. Kruk, and E. Kovačević-Galović, "Rudarsko-Geološka Studija Varaždinske Županije," Zagreb, 2015. 
[32] Z. Peh, "Karta mineralnih sirovina RH." [Online]. Available: https://www.hgi-cgs.hr/ karta-mineralnih-sirovina-RH.htm.

[33] A. Grizelj, Z. Peh, D. Tibljaš, M. Kovačić, and T. Kurečić, "Mineralogical and geochemical characteristics of Miocene pelitic sedimentary rocks from the south-western part of the Pannonian Basin System (Croatia): Implications for provenance studies," Geosci. Front., vol. 8, no. 1, pp. 65-80, 2017.

[34] I. Kovačević, "Eksploatacija i upotreba ciglarske gline u Republici Hrvatskoj," University of Zagreb, 2015.

[35] M. Murat, "Hydration reaction and hardening of calcined clays and related minerals.," Cem. Concr. Res., vol. 13, no. 4, pp. 511-518, Jul. 1983. 